\title{
Experience of medical schools functioning in the USSR during World War II
}

\author{
Marina N. Svintsova ${ }^{1 *}$ and Mihail A. Smirnov ${ }^{2}$ \\ ${ }^{1}$ Financial University under the Government of the Russian Federation, Department of Humanities, \\ Moscow, Russia \\ ${ }^{2}$ Vyatka State University, Law Institute, Department of Theory and History of State and Law, Kirov, \\ Russia
}

\begin{abstract}
The pandemic environment, which emerged in 2020, makes it clear that analysis of historical experience of adaptation of expert training system during crises is very urgent. This article discusses the experience of medical schools in the Soviet Union during World War II, adaptation and rearrangement of the system under difficult crisis conditions, their results. New tasks of medical schools are determined, which occurred during the war, and methods of their solution. It is concluded that high shortage of medical doctors occurring with entry of the Soviet Union into the war was overcome by means of preservation (evacuation) and expansion (establishment of new medical schools, departments and courses, reorganization and reprofiling) of the base for medical personnel training, as well as emergency rearrangement of unified national educational plans and programs of medical doctors' training. The principle of medical education established by the Soviet system of qualified medical personnel training during the war as well as the measures, coordinated by various federal and republican authorities regarding medical school, demonstrated their efficiency.
\end{abstract}

Keywords: medical education, World War II, the Great Patriotic War, USSR.

\section{Introduction}

The COVID-19 pandemic in 2020 demonstrated the vulnerability of a modern human and the level of society readiness for global challenges. The load fell onto doctors' shoulders, their shortage has increased with adaptation of national systems of health care. It is important to analyze historical experience of medical provision, personnel training, and rearrangement of interaction in society in emergency cases (war, epidemic). This subject is of interest not only for Russian but also for the world historiography [1-5].

This work is aimed at analysis of adaptation and operation of medical schools during the Great Patriotic War in the Soviet Union.

The principle established by the Soviet system of qualified medical personnel training during the war demonstrated its efficiency.

\footnotetext{
* Corresponding author: $\underline{\text { mnsvintsova@,fa.ru }}$
} 


\section{Methods}

Comprehensive study of the issue should be based on statistical analysis and comparative analysis of provision of military and civilian health care by high medical personnel, as well as local studies allowing to disclose nuances of personnel reproduction mechanism.

\section{Results}

The entry of the Soviet Union into the war in June, 1941 required for transformation of personnel training system: there appeared the shortage of medical doctors, specificity of losses and illnesses of war time required modification of their specialty and science topics of universities. It was necessary to preserve the material base of universities, to accelerate training and to increase the number of medical doctors at the same quality of personnel training.

The first category of the measures was comprised of evacuation of the existing universities, establishment of new medical schools and specialized departments at civil medical universities; the second category involved solution to staff tasks including changes in education plans, terms of learning, and enrollment of attendees.

\section{Discussion}

The number of graduated medical doctors in the Soviet Union increased in the 1930s.

Table 1. Number of graduates of medical universities in the Soviet Union in the 1930-s [6: 36].

\begin{tabular}{|c|c|}
\hline Year & Medical doctors, pharmacist and physical culture specialists \\
\hline 1934 & 2.5 thousand \\
\hline 1935 & 7.5 thousand \\
\hline 1936 & 9.2 thousand \\
\hline 1937 & 12.3 thousand \\
\hline 1938 & 13.6 thousand \\
\hline
\end{tabular}

In 1939-1940 wide-scale activity was carried out aimed at development of unified textbooks for overall country. Before the Great Patriotic War, the staff of medical universities included 19.8 thousand professors and post-graduates, more than in pedagogical (18.2 thousand) and engineering (9.6 thousand) universities, which demonstrated the levels of demands and the growth rates of health care. 142 thousand doctors with higher medical education worked in health care entities [6].

In pre-war time, about 700 universities operated in the Soviet Union (683 universities as for 1938) [6], among them in 1941, 72 medical universities were in operation (115 thousand medical students) [7], 63 of them were civil medical universities (105 thousand students) [7].

When the war began, 70 thousand medical doctors from civil medical care entities were called for to front [7]: about one half of all personnel; 19 medical universities were closed (Voroshilov Medical University, Stalingrad Medical University, and others [6]). On the forefront line, the shortage of doctors amounted to $40 \%$ [8]. According to available data, during the war 84,793 medical workers were killed or missed in action, including 5,319 medical doctors, 9,198 nurses, 22,723 combat medics, 47,553 attendants and stretch-bearers [8].

Before 1939 the military medical doctors and senior medical personnel were trained only in Kirov Military Medical Academy in Leningrad, then the Kuibyshev Military Medical Academy of the Red Army was established [7], and in 1941 - Moscow Medical University of War Time. 
In 1939 by virtue of joint decision of People's Commissariat of Defense, People's Commissariat of Public Health, and All-Union Committee for Higher Education, military departments were established at civil medical universities: the Second Moscow and Saratov Medical Universities, the First Kharkov Pharmaceutical Institute, and others [9]. In 1940 Military Naval Medical Academy was created, in 1944 - Yaroslavl Medical University [10].

In the temporarily occupied western territories of the Soviet Union in 1941-1945, 334 universities of various specialties were destroyed or damaged, where about 233 thousand students learnt. Technical infrastructure of higher schools was damaged: buildings, laboratories, libraries, equipment, all this affected the training quality. 250 universities were evacuated under the guidance of All-Union Committee for Higher Education [6].

In 1941 the First Moscow State Medical University was evacuated to Ufa. In 1943 Minsk and Vitebsk State Medical Universities were transferred from Belarus to Yaroslavl [10], Kiev Medical Institute - to Chelyabinsk [11], Smolensk State Medical University - partially to Saratov [12: 16]. In 1942 on the basis of the evacuated medical universities, the new Krasnoyarsk State Medical University was established [13]. Kuban Medical Institute was evacuated to Tyumen, North Ossetian State Medical University - to Yerevan, Rostov State Medical University - partially to Central Asia and Kuibyshev, Dagestan State Medical University - to Derbent [14]. Tartar Autonomous Soviet Socialist Republic accepted in evacuation People's Commissariats of the USSR and RSFSR as well as 42 medical universities [7]. Medical doctors were trained by Kazan state medical university. Reverse evacuation of most universities started in 1943-1944 and continued up to the end of the war.

The evacuated universities assisted in settlement of epidemic situation in regions, training of nurses and medical attendants, solving local sanitary problems. Scientific staff practiced in military and civil hospitals, the students were interning there as well as performing research.

Great role in doctors' training was played by the advanced training medical courses established by the Head military sanitary department in military districts and at the fronts. The central institute of advanced training prepared 31,799 medical doctors $(6,169$ surgeons, 1,533 therapists, 1,183 toxicologists, 952 epidemiologists) [8].

In 1941 the medical service of the troops began to be manned by graduates of medical schools in addition to the basic medical staff. People's Commissariat of Public Health of the RSFSR organized early graduation of medical students of the 4th and 5th years, providing at once 14 thousand medical doctors for the front [15]. The admission of applicants to universities decreased, many professors and postgraduate students were sent to the front as political instructors and commanders. Medical universities, aiming at elimination of shortage of doctors in the country, held an additional enrollment. The number of women professors and students in universities has increased [16, 17]. In 1945-1946 the number of students in medical universities exceeded the pre-war indices.

The order of General Staff of the Red Army dated June 30, 1941 introduced the war time curriculum. The time of education was reduced from 5 to 3.5 years and from 4 to 3 years; however, the total academic hours were retained, the daily rate of working hours was increased, vacations and practice were reduced [6]. Lecture streams at the first training courses in medical universities were expanded, at senior courses they were replaced by selftraining and practice, the students combined study and work. The efficiency of the adopted measures was moderate, and the enrollment of 1942-1943 was again transferred to complete education terms.

The portion of military (marching drill, bayonet fighting, and others) and military medical disciplines as well as of physical training in the education program of medical doctors was increased. Higher attention was paid to humanitarian disciplines aiming at political and ideological training of doctors, to historical disciplines in combination with contemporaneity 
as an educational component, constituent of political competence and position of a gradate, preservation of foundations of moral culture despite war time [15].

Peculiar attention was paid to talented students, they were preliminary allowed to perform research studies at specialized departments of medical universities [12].

The war affected the subject matter and volume of scientific work in universities. During the first year and a half some research studies did not comply with the demands of war time and were stipulated by the area of interest of researching doctors. The need to eliminate the consequences of combat actions restructured scientific work on treatment of injuries and illnesses of war time caused by the war specificity, propagation of infections and shortage of food products for population.

\section{Conclusion}

During 1941-1945 the integrated and centralized rearrangement of medical personnel training for army, navy, and civil health care proved to be successful and could solve the formulated problems. Civil universities educated more than 65 thousand medical doctors for acting army, 80 thousand medical doctors were recalled [7], staff shortage was eliminated.

\section{Acknowledgments}

This work was supported by the Scientific Foundation of Financial University.

\section{References}

1. H. Dokter, Medical student during World War II (2011). Accessed on: December 15, 2020. [Online]. Available: http

https://www.researchgate.net/publication/291688701_Medical_student_during_World_ War_II

2. R.D. Markwick, E.Ch. Cardona, Soviet women on the frontline in the Second World War (Palgrave Macmillan, New York, 2012)

3. R.J. Parks, Medical training in World war II (US Government Printing Office, Washington, 1974)

4. K. O’Flynn, Medical Education, 40(3), 235-242 (2006). https://doi.org/10.1111/j.1365-2929.2006.02388.x .

5. I.R Whitehead, Doctors in the Great War (CPI Group Ltd, Croydon, 2013)

6. N.L. Sivertseva, Sotsiologicheskie Issledovaniia [Sociological Research], 5, 35-44 (1995)

7. I.M. Chizh, S.N. Rusanov, Voyenno-Meditsinskiy Zhurnal [Military Medical Journal], 337(10), 71-77 (2016)

8. Velikaia Otechestvennaia voina 1941-1945 godov [The Great Patriotic War of 194145], in Itogi i uroki voiny [Results and lessons of the war], Volume 12 (Moscow, Kuchkovo pole, 2015)

9. E.I. Smirnov (Ed.), Voyenno-meditsinskoye obrazovaniye [Military medical education], in Entsiklopedicheskiy slovar' voyennoy meditsiny [Encyclopedic Dictionary of Military Medicine], Volume 1 (Gosudarstvennoye izdatelstvo meditsinskoy literatury, Moscow, 1946)

10. N.T. Eregina, E.M Smirnova, Vysshee Obrazovanie v Rossii [Higher education in Russia], 8-9, 91-97 (2014) 
11. Y.A. Tyukov, I.S. Tarasova, E.Y. Vanin, E.S. Matveeva, Bulletin of Semashko National Research Institute of Public Health, 2, 365-366 (2016)

12. V.M. Ostapenko, S.V. Nagornaya, Vestnik Smolenskoj Gosudarstvennoj Medicinskoj Akademii [Bulletin of the Smolensk State Medical Academy], 14(1), 14-18 (2015)

13. I.I. Nikolaeva, E.S. Bannova, Meditsina i Obrazovaniye v Sibiri [Medicine and Education in Siberia], 4, 11-17 (2007)

14. R.S. Spevak, A.V. Kartashev, The Humanities and Social-Economic Sciences, 3(82), 63-68 (2015)

15. V.P. Byakina, I.V. Zimin, L.G. Kondrashkina, The Scientific Notes of the Pavlov University, 16(1), 5-7 (2009)

16. A.M. Shelepov, O.A. Kryuchkov, Vestnik Rossiyskoy Voyenno-Meditsinskoy Akademii [Bulletin of the Russian Military Medical Academy], 1(29), 196-199 (2010)

17. N.A. Orekhovskaya, A.G. Tyurikov, P.V. Razov, M.V. Kibakin, N.I. Kiseleva, Eurasian Journal of Analytical Chemistry, 12(7b), 1283-1289 (2017).

https://doi.org/10.12973/ejac.2017.00254a 